\title{
A case study of aerosol processing and evolution in summer in New York City
}

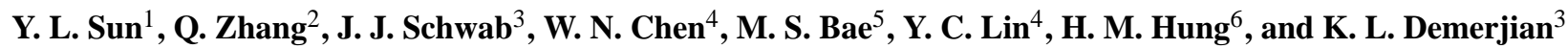 \\ ${ }^{1}$ State Key Laboratory of Atmospheric Boundary Layer Physics and Atmospheric Chemistry, \\ Institute of Atmospheric Physics, Chinese Academy of Sciences, Beijing, China \\ ${ }^{2}$ Department of Environmental Toxicology, University of California, Davis, California, USA \\ ${ }^{3}$ Atmospheric Sciences Research Center, State University of New York, Albany, New York, USA \\ ${ }^{4}$ Research Center for Environmental Changes, Academia Sinica, Taipei, Taiwan \\ ${ }^{5}$ Environmental Engineering Department, Mokpo National University, South of Korea \\ ${ }^{6}$ Department of Atmospheric Sciences, National Taiwan University, Taipei, Taiwan
}

Received: 2 September 2011 - Published in Atmos. Chem. Phys. Discuss.: 15 September 2011

Revised: 21 November 2011 - Accepted: 7 December 2011 - Published: 16 December 2011

\begin{abstract}
We have investigated an aerosol processing and evolution event from 21-22 July during the summer 2009 Field Intensive Study at Queens College in New York City (NYC). The evolution processes are characterized by three consecutive stages: (1) aerosol wet scavenging, (2) nighttime nitrate formation, and (3) photochemical production and evolution of secondary aerosol species. Our results suggest that wet scavenging of aerosol species tends to be strongly related to their hygroscopicities and also mixing states. The scavenging leads to a significant change in bulk aerosol composition and average carbon oxidation state because of scavenging efficiencies in the following order: sulfate $>$ low-volatility oxygenated organic aerosol (LV-OOA) $>$ semi-volatile OOA (SV-OOA) > hydrocarbon-like OA (HOA). The second stage involves a quick formation of nitrate from heterogeneous reactions at nighttime. During the third stage, simultaneous increases of sulfate and SV-OOA were observed shortly after sunrise, indicating secondary aerosol formation. Organic aerosols become highly oxidized in $\sim$ half day as the result of photochemical processing, consistent with previously reported results from the CO-tracer method $(\mathrm{OA} / \Delta \mathrm{CO})$. The photochemical reactions appear to progress gradually associated with a transformation of SVOOA to low-volatility species based on the evolution trends
\end{abstract}

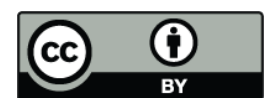

Correspondence to: $\mathrm{Q}$. Zhang

(dkwzhang@ucdavis.edu) of oxygen-to-carbon $(\mathrm{O} / \mathrm{C})$ ratio, relationship between $\mathrm{f} 44$ (fraction of $m / z 44$ in OA) and $\mathrm{f} 43$ (fraction of $\mathrm{m} / \mathrm{z} 43$ in OA), and size evolution of OOA and HOA. Aerosols appear to become more internally mixed during the processing. Our results suggest that functionalization by incorporation of both $\mathrm{C}$ and $\mathrm{O}$ plays a major role in the early period of OA oxidation $(\mathrm{O} / \mathrm{C}<0.5)$. Our results also show that photochemical production of LV-OOA during this event is approximately 2$3 \mathrm{~h}$ behind of sulfate production, which might explain, sometimes, the lack of correlations between LV-OOA and sulfate, two secondary aerosol species which often exist in internal mixtures over regional scales.

\section{Introduction}

Atmospheric aerosols, consisting of liquid and solid particles suspended in the air, are important components of atmosphere. Aerosols play a significant role in visibility reduction (Watson, 2002), regional air pollution (Molina and Molina, 2004), and climate change (IPCC, 2007). Aerosols and their associated direct and indirect effects on radiative forcing are highly uncertain (Forster et al., 2007) due to a lack of knowledge on their sources, composition, evolution processes and deposition (Pöschl, 2005; Hallquist et al., 2009). Particularly, organic aerosols (OA), accounting for a large fraction of submicron aerosol mass (Kanakidou et al., 2005; Zhang et

Published by Copernicus Publications on behalf of the European Geosciences Union. 
al., 2007a; Jimenez et al., 2009), are most poorly understood because of their complex and diverse volatilities, functionalities, and solubilities. Aerosols also exert a serious impact on human health by increasing the damage of respiratory and cardiovascular systems and reducing life expectancy (Pope et al., 2002, 2009).

Atmospheric aerosols are formed from various emission sources and transformation processes. Aerosol particles can be primary from the direct emissions (e.g. combustion of fossil fuels, biomass burning, mineral dust and sea salt) or secondary from gas-to-particle transformation processes such as nucleation and heterogeneous reactions. Although primary emissions of aerosols and secondary formation of inorganic species (e.g. sulfate and nitrate) are fairly well understood, there is considerable uncertainty on the formation of secondary organic aerosol (SOA) (Hallquist et al., 2009). For example, traditional SOA models only considering SOA formation from volatile organic compounds (VOCs) often greatly underestimate the observed SOA (Heald et al., 2005; Volkamer et al., 2006; Dzepina et al., 2009; Wood et al., 2010). In addition to source emissions and secondary formation, other dominant processes affecting ambient aerosol concentrations include cloud processing, additional OA aging, wet deposition by precipitation, and dry deposition by convective transport and diffusion (Pöschl, 2005). The chemical and physical properties of aerosol particles such as chemical composition, size distribution, and oxidation state may change significantly because of these evolution processes. Thus a comprehensive characterization and understanding of aerosol evolution processes is required for mitigating aerosol effects on climate and public health.

In summer 2009, we returned to Queens College (QC) in New York City (NYC), previously an EPA supersite during PMTACS-NY, with an Aerodyne High-Resolution Time-ofFlight AMS (HR-AMS; DeCarlo et al., 2006), to study submicron aerosol chemistry and processes (Sun et al., 2011a). In comparison to the Quadrupole AMS (Q-AMS) system deployed in 2001 and 2004 (Drewnick et al., 2004a, b; Weimer et al., 2006), HR-AMS has significantly improved chemical resolution and sensitivity, allowing greater details to be gained about the chemical composition and atmospheric processing of OA. The real-time, highly time-resolved $(5 \mathrm{~min}$ resolution) concentrations and size distributions of nonrefractory submicron aerosol (NR-PM 1 ) species (i.e. organics, sulfate, nitrate, ammonium, and chloride) were measured in-situ from 13 July through 3 August to investigate the sources and evolution processes of submicron aerosols in NYC. The mass concentrations, size distributions, chemical composition, and temporal and diurnal variations of NR species, elemental composition of $\mathrm{OA}$, and investigations of sources and processes of OA components have been detailed in Sun et al. (2011a).

In this study, we analyzed a 2-day aerosol processing and evolution event from 21-22 July which we interpret as a progression of three typical atmospheric processes. The whole process started with a quick wet scavenging of inorganic species and secondary OA, followed by a nighttime nitrate formation process, and then photochemical production and aging after sunrise. Here we present a detailed investigation of these processes focusing on (1) the relationship between scavenging rates and properties of aerosol species, (2) the impacts of wet scavenging on aerosol composition, mixing states, and oxidative properties, (3) the formation mechanisms of nitrate, and (4) the photochemical production and aging of secondary inorganic and organic species.

\section{Methods}

\subsection{Aerosol sampling}

Submicron aerosol particles were measured in-situ from 13 July through 3 August 2009 on the campus of Queens College $\left(40.74^{\circ} \mathrm{N}, 73.82^{\circ} \mathrm{W}\right)$ by an Aerodyne HR-AMS. The HR-AMS was deployed inside the state-of-the-art Atmospheric Sciences Research Center-Mobile Laboratory (ASRC-ML) (Lin et al., 2011) along with various fastresponse aerosol and gas instruments. During the 3-week continuous measurements, the ASRC-ML was parked at Lot 6, which is approximately $500 \mathrm{~m}$ south of the Long Island Expressway (LIE, I-495) and $1.2 \mathrm{~km}$ east of the Van Wyck Expressway (I-678), two high-traffic highways in the NYC metropolitan area.

The HR-AMS was operated under the sensitive V-mode and the high mass resolution $(\sim 6000) \mathrm{W}$-mode alternatively every $5 \mathrm{~min}$. Under V-mode operation, the AMS cycled through the mass spectrum (MS) mode and the particle timeof-flight (PToF) mode every $30 \mathrm{~s}$. No PToF data were sampled in $\mathrm{W}$-mode due to limited signal-to-noise $(\mathrm{S} / \mathrm{N})$ ratio. The HR-AMS was calibrated for ionization efficiency (IE) and particle sizing at the beginning and in the middle of this study following the standard protocols (Jayne et al., 2000; Jimenez et al., 2003; Drewnick et al., 2005). Detailed descriptions of the sampling site and instrument operations are given in Sun et al. (2011a).

\subsection{Collocated measurements}

The synchronous measurements in ASRC-ML include absorption coefficient $\left(B_{\mathrm{abs}}\right)$ by a DMT single-wavelength Photoacoustic Soot Spectrometer (PASS-1), formaldehyde ( $\mathrm{HCHO}$ ) and $\mathrm{NO}_{2}$ by an Aerodyne Quantum Cascade Laser (QCL) Spectrometer, $\mathrm{CO}_{2}$ and $\mathrm{H}_{2} \mathrm{O}$ by a Li-COR $\mathrm{CO}_{2}$ analyzer, trace gases of $\mathrm{O}_{3}, \mathrm{NO}$, and $\mathrm{NO}_{2}$ by $2 \mathrm{~B}$ technologies analyzers, VOCs by a BTEX (benzene, toluene, ethylbenzene, and xylene) analyzer, and size-resolved number concentrations by a TSI Fast Mobility Particle Sizer (FMPS, Model $3091,5.6-560 \mathrm{~nm}$ ) spectrometer. In addition to measurements from the ASRC-ML, aerosol and gas species were also measured inside the New York State Department of Environmental Conservation (NYS DEC) Air Monitoring Building, 
$\sim 140 \mathrm{~m}$ north of Lot 6 . Detailed descriptions of this site are given in Drewnick et al. (2004a) and Weimer et al. (2006). The key measurements at this site included water-soluble ions by a Particle-into-Liquid Sampler (PILS) coupled with two Ion Chromatographs (IC), chemical composition and mass concentrations of NR-species by an Aerodyne Aerosol Chemical Speciation Monitor (ACSM), Organic carbon (OC) and elemental carbon (EC) by a Sunset Labs OC/EC Analyzer, sulfate by a Thermo Electron 5020 Sulfate Particulate Analyzer, and $\mathrm{PM}_{2.5}$ mass by a Tapered Element Oscillating Microbalance (TEOM). Other collocated measurements such as trace gases and number concentrations are detailed elsewhere (Sun et al., 2011a).

\subsection{AMS data analysis}

The aerosol mass spectrometry data were analyzed to determine the mass concentrations and size distributions of NR$\mathrm{PM}_{1}$ species with the standard AMS data analysis software (SQUIRREL v1.46, Sueper, 2011) and the ion-speciated composition and elemental composition, i.e., oxygen-tocarbon $(\mathrm{O} / \mathrm{C})$, hydrogen-to-carbon (H/C), nitrogen-to-carbon (N/C), and organic mass-to-organic carbon (OM/OC) ratios with the high resolution data analysis software (PIKA, v1.06) and APES (v1.04A). The PMF2 algorithm (v4.2) (Paatero and Tapper, 1994) is used in robust mode to unravel AMS high resolution mass spectra (HRMS) into distinct OA components, performed with an Igor Pro-based PMF Evaluation Tool (PET, v2.04) (Ulbrich et al. 2009). PMF2 solutions were thoroughly evaluated using the procedures given by Ulbrich et al. (2009) and summarized in Table 1 in Zhang et al. (2011). Five OA components, i.e. hydrocarbon-like OA (HOA), cooking-related OA (COA), regional, highly aged low-volatility oxygenated OA (LV-OOA), less photochemically aged semi-volatile oxygenated OA (SV-OOA), and a unique nitrogen-enriched OA (NOA) were identified (Sun et al., 2011a). Each component demonstrates distinct temporary variation and mass spectral patterns that are indicative of their associations with unique sources and processes. More details on AMS data analysis can be found in Sun et al. (2011a).

A tracer $m / z$-based method was used to derive the size distributions of HOA and OOA in Pittsburgh based on those of $\mathrm{m} / \mathrm{z}_{4} 4 \mathrm{and} \mathrm{m} / \mathrm{z} 57$ after subtracting OOA contribution (2\% of $\mathrm{m} / z 44$, mainly $\mathrm{C}_{3} \mathrm{H}_{5} \mathrm{O}^{+}$) from the measured $\mathrm{m} / z 57$ size distribution data (Zhang et al., 2005c). This method was used because only eight organic $\mathrm{m} / \mathrm{z}$ 's were acquired using a Q-AMS (Zhang et al., 2005b). In this study, the size distributions of $\mathrm{m} / \mathrm{z}$ 's up to 300 were obtained with a time-offlight mass spectrometer, allowing us to apply the custom principal component analysis (CPCA) technique (Zhang et al., 2005a) to the 3-dimentional size-resolved mass spectra (dimensions: date/time, size, and $\mathrm{m} / \mathrm{z}$ ) to determine the size distributions of OA components. To improve the S/N, we averaged the 102 size bins acquired between $30-1500 \mathrm{~nm}\left(D_{\text {va }}\right)$ into 20 bins before performing CPCA analysis to the sizeresolved mass spectra for 21-24 July. The tracer $m / z$-based method was performed as a comparison. Figure $\mathrm{S} 1$ shows the mass spectra of HOA and OOA determined for different size bins, and their correlations with those identified from PMF analysis of OA spectra acquired under the MS mode (i.e. not size resolved). The HOA between $\sim 60-800 \mathrm{~nm}$ and OOA between $\sim 150-800 \mathrm{~nm}$ show overall similar spectral patterns to the reference spectra of HOA and OOA, respectively. The weak correlations below $60 \mathrm{~nm}$ and above $800 \mathrm{~nm}$ for HOA and below $150 \mathrm{~nm}$ and above $800 \mathrm{~nm}$ for OOA are likely due to poor $\mathrm{S} / \mathrm{N}$, partly due to limited AMS transmission efficiencies for these particles (Liu et al., 2007) and gas phase $\mathrm{CO}_{2}$ interferences in the ultrafine mode of the $\mathrm{m} / \mathrm{z} 44$ size distribution data. A comparison between CPCA and the tracer $m / z$-based indicates that both report very similar size distribution patterns but the tracer $m / z$-based approach seems to report lower HOA during OOA dominant periods, and lower OOA during HOA dominant periods (Fig. S2). Detailed analysis and interpretation of size-resolved mass spectra will be presented elsewhere.

All the data in this study are reported for ambient temperature and pressure conditions in Eastern Standard Time (EST), which equals Coordinated Universal Time (UTC) minus $5 \mathrm{~h}$ or local Time (i.e. East Daylight Time - EDT) minus $1 \mathrm{~h}$.

\section{Results and discussions}

Figure 1 shows the time series of meteorological variables, mixing ratios of gaseous species, mass concentrations and fractions of NR-PM 1 species and OA components, and O/C ratio of OA from 21-22 July. Overall, the aerosol processing during these two days can be classified into three stages: (I) aerosol wet scavenging, (II) night time nitrate formation, and (III) photochemical production and aging of secondary aerosol species. In the following sections, we describe the three stages in detail, each of which represents an important process of aerosol particles in the atmosphere.

\subsection{Aerosol wet scavenging}

This stage started with a light rain at $\sim 03: 00$ in the morning of 21 July. The rain lasted till $\sim 19: 00$ at night. During the 16-h period, air temperature remained mild at $\sim 20^{\circ} \mathrm{C}$, relative humidity was close to $100 \%$, solar radiation was low, and the wind was consistently from the northeast with speed of $<\sim 2 \mathrm{~m} \mathrm{~s}^{-1}$ (Fig. 1). The ammonium sulfate and LV-OOA concentrations decreased slowly at the beginning, followed by rapid scavenging due to the intense precipitation between 05:00-09:00. Other aerosol species (e.g. HOA, nitrate, and chloride), however, showed little changes in concentration and even slight increases (Fig. 1f, h), for which the relatively shallow planetary boundary layer height (due to cool temperature and overcast conditions) might have played some roles. 
Table 1. Scavenging rates of selected aerosol species, ion families, and $\mathrm{OA}$ tracer ions in mass concentrations $(\Delta C / \Delta t)$ and in percentages $(\Delta \% / \Delta t)$. The negative values indicate the scavenged species. $\Delta \% / \Delta t=(\Delta C / \Delta t) / C_{i} \times 100$, where $C_{i}$ is the initial concentration of species $i$.

\begin{tabular}{lrr}
\hline Species & $\begin{array}{r}\Delta C / \Delta t \\
\left(\mathrm{ng} \mathrm{m}^{-3} \mathrm{~h}^{-1}\right)\end{array}$ & $\begin{array}{r}\Delta \% / \Delta t \\
\left(\% \mathrm{~h}^{-1}\right)\end{array}$ \\
\hline Sulfate & -267 & -6.0 \\
Nitrate & -0.6 & -0.1 \\
LV-OOA & -126 & -4.8 \\
NOA & -0.7 & -0.4 \\
SV-OOA & 4.7 & 1.1 \\
$\mathrm{COA}$ & 45 & 115 \\
$\mathrm{HOA}$ & 8.4 & 2.2 \\
$\mathrm{C}_{\mathrm{x}} \mathrm{H}_{\mathrm{y}} \mathrm{O}_{2}^{+}$ & -4.4 & -3.8 \\
$\mathrm{C}_{\mathrm{X}} \mathrm{H}_{\mathrm{y}} \mathrm{O}_{1}^{+}$ & -1.8 & -2.5 \\
$\mathrm{C}_{\mathrm{X}} \mathrm{H}_{\mathrm{y}}^{+}$ & 1.3 & 0.1 \\
$\mathrm{CO}_{2}^{+}$ & -18.5 & -4.1 \\
$\mathrm{C}_{2} \mathrm{H}_{3} \mathrm{O}^{+}$ & -4.0 & --2.1 \\
$\mathrm{C}_{4} \mathrm{H}_{9}^{+}$ & 1.2 & 3.4 \\
\hline
\end{tabular}

The slight increase of HOA is also likely due to constant inputs from local emissions, in agreement with the variations of primary gaseous tracers for traffic emissions, e.g. NO, $\mathrm{NO}_{2}$, and $\mathrm{CO}_{2}$. The scavenging process led to a significant change in aerosol composition, as indicated by the variations in the mass fractions of aerosol species (Fig. 1g, i). Over the course of scavenging, organics gradually became the dominant component, contributing up to $70 \%$ of the total NR$\mathrm{PM}_{1}$ while ammonium sulfate only accounted for a minor fraction $(<20 \%)$ at the end of the scavenging. In contrast, the concentrations of EC and HOA remained relatively flat during this stage, showing small enhancements during morning rush hours (Fig. 1d, f). The OA composition also showed a dramatic change with a significant reduction of SOA $(=\mathrm{LV}$ $\mathrm{OOA}+\mathrm{SV}-\mathrm{OOA})$ in association with an increased fraction of $\mathrm{POA}(=\mathrm{HOA}+\mathrm{COA})$.

Table 1 shows the scavenging rates of major aerosol species, ion families and mass spectral tracer ions in mass concentrations and mass percentages. The scavenging rates were calculated by performing linear regression of the mass concentrations between 03:00-19:00. Sulfate showed the highest scavenging rate $\left(267 \mathrm{ng} \mathrm{m}^{-3} \mathrm{~h}^{-1}\right)$ followed by $\mathrm{LV}$ OOA $\left(126 \mathrm{ng} \mathrm{m}^{-3} \mathrm{~h}^{-1}\right)$, corresponding to a scavenging percentage of $6.0 \%$ and $4.8 \%$, respectively. Nitrate, despite its high hygroscopicity, showed almost no removal $(-0.1 \%)$. The apparent low scavenging rate of nitrate is likely due to the competing effects between rainfall scavenging and the continuous, but relatively low, input of nitrate during this stage. Indeed, the photochemical production rate of $\mathrm{HNO}_{3}$ (Sect. 3.2) showed a slight increase after 10:00, indicating the formation of $\mathrm{HNO}_{3}$ that can react with $\mathrm{NH}_{3}$ to form
$\mathrm{NH}_{4} \mathrm{NO}_{3}$. Another possible reason for the persistently low concentration of nitrate is that not all fine particles were efficiently scavenged by rain drops (Andronache, 2003). This might also explain the low but non-zero concentration of sulfate observed at the end of this stage even though the scavenging rate of sulfate is high. The primary OA factors (COA and HOA), as well as EC, showed slight increases despite rain scavenging, part of which was due to local emissions. Especially, the increase of COA was associated with enhanced local cooking activities in the evening. The scavenging rates of aerosol species appear to be closely related to their hygroscopicities which can be described by the hygroscopicity parameter - kappa $(\kappa)$ (Petters et al., 2009). This is consistent with the results from a previous study showing that the scavenging efficiencies are positively related to the polarity and solubilities of compounds (Limbeck and Puxbaum, 2000). Ammonium sulfate is highly hygroscopic with $\kappa=\sim 0.6$ (Petters et al., 2009). The hygroscopicity of OA, however, strongly depends on the oxidation state and degree of aging. A recent study found a positive relationship between the hygroscopicity and the O/C ratio of OA from both field observations and smog chamber results (Jimenez et al., 2009). The results show that the $\kappa$ of OA components with $\mathrm{O} / \mathrm{C}>0.6$ is roughly 0.16 , while those with $\mathrm{O} / \mathrm{C}<\sim 0.3$ are weakly hygroscopic. Chang et al. (2010) postulated a linear relationship between $\kappa_{\mathrm{Org}}$ and $\mathrm{O} / \mathrm{C}$ in that $\kappa_{\mathrm{Org}}=0.29 \times \mathrm{O} / \mathrm{C}(\mathrm{O} / \mathrm{C}=0.3-0.6)$ based on AMS and $\mathrm{CCN}$ measurements at a rural site in Ontario, Canada. Massoli et al. (2010) further investigated the relationship between oxidation level and hygroscopic properties of SOA generated via $\mathrm{OH}$ radical oxidation in an aerosol flow reactor. A non-linear, but positive relationship between $\kappa_{\mathrm{Org}}$ and $\mathrm{O} / \mathrm{C}$ was observed (Massoli et al., 2010), in agreement with those reported previously for OA with comparable $\mathrm{O} / \mathrm{C}$ ratios (Jimenez et al., 2009; Chang et al., 2010).

According to the findings above, LV-OOA with $\mathrm{O} / \mathrm{C}$ of 0.63 ( $\kappa$ estimated at $\sim 0.2$ ) would be the most hygroscopic among the five OA factors, SV-OOA $(\mathrm{O} / \mathrm{C}=0.38)$ is weakly hygroscopic, and COA/HOA with low $\mathrm{O} / \mathrm{C}$ ratios $(0.18$ and 0.06 , respectively) are the least hygroscopic or nonhygroscopic. The scavenging rates are indeed proportional to the $\mathrm{O} / \mathrm{C}$ of OA components following the order of LV$\mathrm{OOA}>\mathrm{SV}-\mathrm{OOA}>\mathrm{COA} / \mathrm{HOA}$, in agreement with the scavenging rates of the tracer ions for $\mathrm{OA}$ components in the order of $\mathrm{CO}_{2}^{+}(\mathrm{m} / \mathrm{z} 44$, a tracer for $\mathrm{LV}-\mathrm{OOA})>\mathrm{C}_{2} \mathrm{H}_{3} \mathrm{O}^{+}$ $(\mathrm{m} / \mathrm{z} 43$, a tracer for $\mathrm{SV}-\mathrm{OOA})>\mathrm{C}_{4} \mathrm{H}_{9}^{+}(\mathrm{m} / \mathrm{z} 57$, a tracer for HOA) (Table 1). Similarly, oxygenated ion families of $\mathrm{C}_{\mathrm{x}} \mathrm{H}_{\mathrm{y}} \mathrm{O}_{2}^{+}$and $\mathrm{C}_{\mathrm{x}} \mathrm{H}_{\mathrm{y}} \mathrm{O}_{1}^{+}$were scavenged more efficiently at a rate of $3.8 \%$ and $2.5 \%$, respectively, in comparison to hydrocarbon ions $\mathrm{C}_{\mathrm{x}} \mathrm{H}_{\mathrm{y}}^{+}(0.1 \%)$. Similar conclusions were obtained by investigating the scavenging efficiencies of aerosol components in clouds (Sellegri et al., 2003). The less-volatile fraction of $\mathrm{OA}$, which was internally mixed with inorganic species in the accumulation mode $(\sim 500 \mathrm{~nm})$, was 

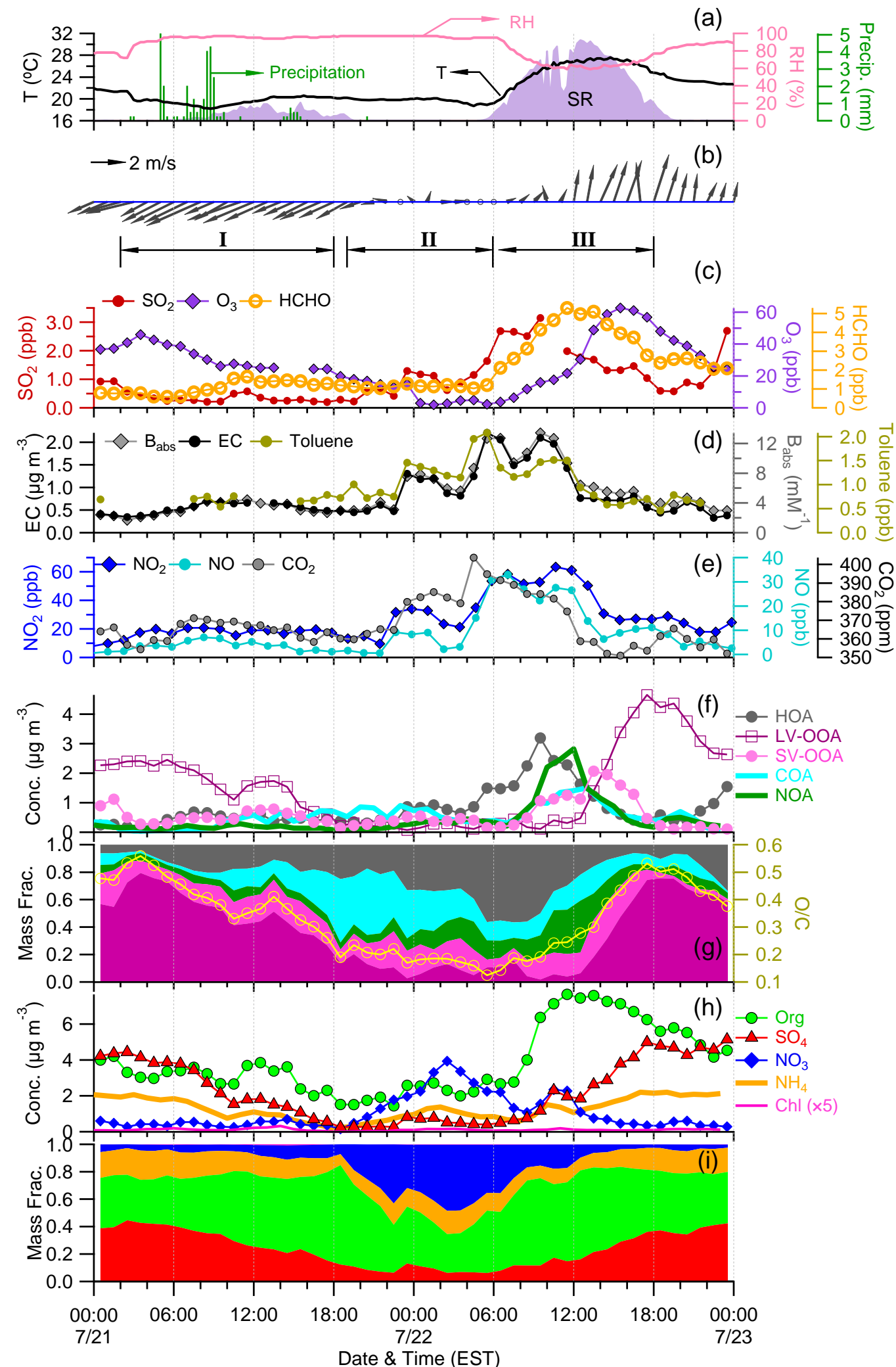

(b)

Fig. 1. Time series of (a, b) meteorology (relative humidity, temperature, precipitation, solar radiation, wind direction, and wind speed), $(\mathbf{c}, \mathbf{d}, \mathbf{e})$ gaseous species, EC, and absorption ( $B_{\text {abs }}$ ), hourly average mass concentrations and fractions of (f, g) OA components (LV-OOA, SV-OOA, HOA, COA, and NOA), and O/C ratio of OA, and (h, i) NR species (organics, sulfate, ammonium, nitrate, and chloride) from 21-22 July. Three stages representing different atmospheric processes are marked as I, II, and III, respectively. 
(a)
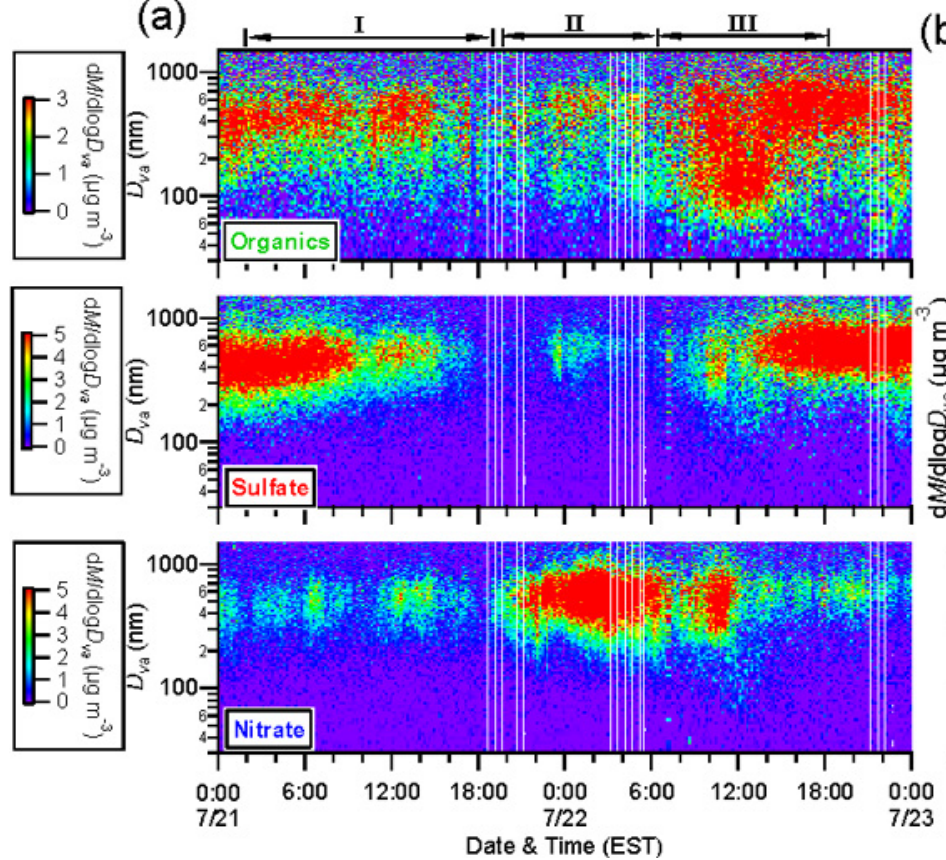

(b)
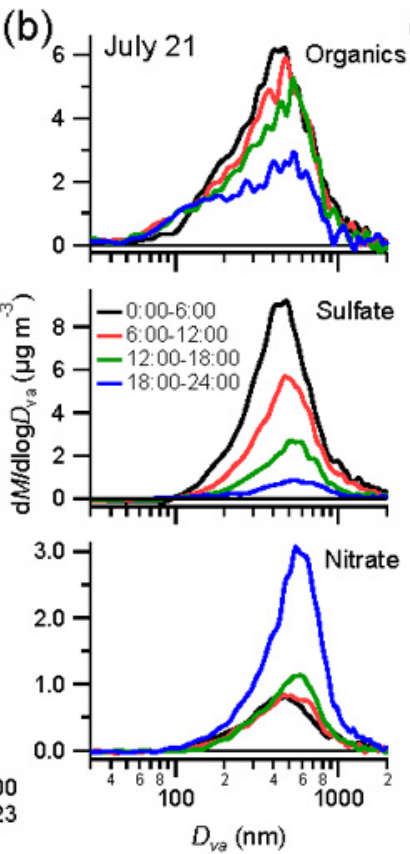
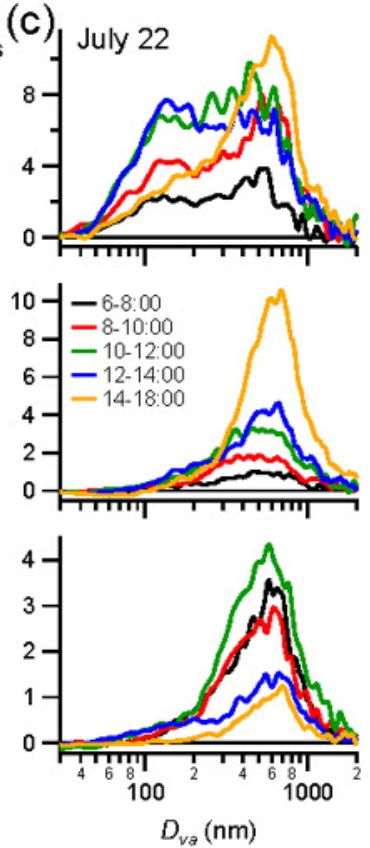

Fig. 2. Evolution of size distributions for the mass concentrations of organics, sulfate, and nitrate. (b, c) shows the average size distributions of aerosol species for selected time ranges on 21 and 22 July, respectively.

found to be better scavenged compared to the more-volatile fraction (Sellegri et al., 2003). It should be noted that the scavenging process is not only related to the hygroscopicity, but also to the mixing state of aerosol species, and the intensity and the duration of the precipitation. For example, base on the data reported by Huang et al. (2010) and Sun et al. (2010), faster scavenging of aerosol species, typically within a few hours, were observed in Beijing, China where POA species were overall internally mixed with more hygroscopic secondary species. It is important to point out that the observed decreases of aerosol concentration could be attributed to the mixing in of cleaner air masses associated with northeastern wind as well. However, the fact that LV-OOA and sulfate concentrations began to increase upon the ending of the heavy precipitation (at $\sim 09: 00$ ) while the wind direction remained northeast (Fig. 1) suggests that wet scavenging was the dominant process responsible for the decreases in aerosol concentrations during this time period.

In addition to changing aerosol composition, the scavenging process also led to apparent changes in aerosol size distributions (Fig. 2). The peaks of the size distributions of organics, sulfate, and nitrate all shifted to larger sizes during the course of scavenging, possibly due to aerosol growth under high humidity conditions as well as size-dependent scavenging efficiencies (Andronache, 2003). For instance, the accumulation mode of sulfate peaked at $\sim 450 \mathrm{~nm}$ at the beginning of the event, but at $\sim 550 \mathrm{~nm}$ at the end. Similar size growth was also observed for organics and nitrate. It is interesting to note that as the accumulation mode OA evolved into larger sizes, the ultrafine mode $(<150 \mathrm{~nm})$ organics changed little in both concentration and size distribution (Fig. 2b). This mode was dominated by HOA and EC which are overall non-hygroscopic with low scavenging rates.

Figure 3 shows the evolutions of size-resolved HOA and OOA every six hours on 21 July. Although OOA dominated the overall organic mass loading, HOA contributed a major fraction ( $>60 \%$ ) of the ultrafine mode organics. As the scavenging progressed, the mass concentration of HOA showed relatively little variations across the entire size range while that of OOA decreased rapidly, resulting in increased contributions of HOA in both the ultrafine and the accumulation modes. HOA contributed more than $60 \%$ of the accumulation mode at the end of rainfall event. The different scavenging rates for HOA and OOA further caused a significant change in the average oxidation state of OA. As shown in Fig. 1g, the $\mathrm{O} / \mathrm{C}$ ratio during the scavenging period decreased almost linearly from $\sim 0.6$ to $\sim 0.2$, indicating that $\mathrm{OA}$ on average became less oxidized due to the much faster scavenging of OOA than HOA as well as constant inputs of HOA from traffic sources.

\subsection{Nitrate formation}

Stage II is characterized by a quick formation of nitrate that started at $\sim$ 19:00 (sunset time: 19:30) and persisted $\sim$ half day till $\sim 06: 00$ of the 2 nd day (22 July). During this stage, the RH remained high ( $\sim 95-97 \%)$ and the temperature was relatively low $\left(\sim 20^{\circ} \mathrm{C}\right)$. The wind speed was close to zero, 

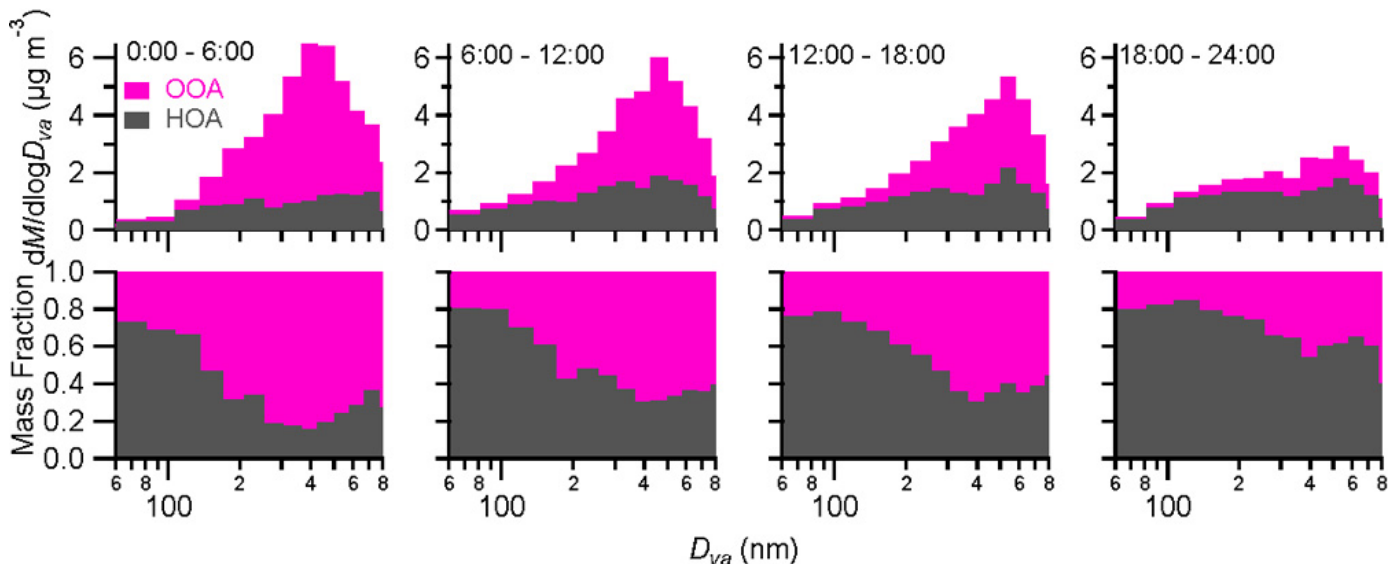

Fig. 3. Average size distributions of HOA and OOA every six hours on $21 \mathrm{July.} \mathrm{In} \mathrm{each} \mathrm{panel,} \mathrm{the} \mathrm{OOA} \mathrm{size} \mathrm{distribution} \mathrm{is} \mathrm{stacked} \mathrm{on} \mathrm{top} \mathrm{of}$ the HOA size distribution.

indicating stagnant air. Atmospheric nitrate formation pathways mainly include heterogeneous hydrolysis of $\mathrm{N}_{2} \mathrm{O}_{5}$ at nighttime and gas-phase photochemical production of $\mathrm{HNO}_{3}$ during daytime. The nitrate ambient concentration is also driven by gas-to-particle partitioning of ammonium nitrate and boundary layer dynamics (Seinfeld and Pandis, 2006). The nocturnal formation of nitrate involves the following key steps (reactions R1-R5) (Brown et al., 2006):

$$
\begin{aligned}
& \mathrm{NO}_{2}+\mathrm{O}_{3} \rightarrow \mathrm{NO}_{3}+\mathrm{O}_{2} \\
& \mathrm{NO}_{2}+\mathrm{NO}_{3}+\mathrm{M} \leftrightarrow \mathrm{N}_{2} \mathrm{O}_{5}+\mathrm{M} \\
& \mathrm{N}_{2} \mathrm{O}_{5}+\mathrm{H}_{2} \mathrm{O}(\mathrm{aq}) \rightarrow 2 \mathrm{HNO}_{3} \\
& \mathrm{HNO}_{3}(\mathrm{~g})+\mathrm{NH}_{3}(\mathrm{~g}) \leftrightarrow \mathrm{NH}_{4} \mathrm{NO}_{3}(\mathrm{~s})(\mathrm{RH}<\mathrm{DRH}) \\
& \mathrm{HNO}_{3}(\mathrm{~g})+\mathrm{NH}_{3}(\mathrm{~g}) \leftrightarrow \mathrm{NH}_{4}^{+}(\mathrm{aq})+\mathrm{NO}_{3}^{-}(\mathrm{aq})(\mathrm{RH}>\mathrm{DRH}) \\
& \mathrm{NO}_{2}+\mathrm{OH}+\mathrm{M} \rightarrow \mathrm{HNO}_{3}+\mathrm{M} \\
& \mathrm{HNO}_{3}(\mathrm{~g})+\mathrm{NH}_{3}(\mathrm{~g}) \leftrightarrow \mathrm{NH}_{4} \mathrm{NO}_{3}(\mathrm{~s})
\end{aligned}
$$

Where DRH is the deliquescence relative humidity which is $\sim 61 \%$ at $298 \mathrm{~K}$ for ammonium nitrate. Although the gas phase reaction (R3) is very slow, the heterogeneous reaction (R3) can be very fast on aerosol particles at high RH. The mixing ratios of $\mathrm{NO}_{2}$ and $\mathrm{O}_{3}$ at the beginning of stage II were both $\sim 20 \mathrm{ppb}$, and decreased gradually till 23:00 (Fig. 1), likely due to reaction (R1). With the presence of abundant $\mathrm{NH}_{3}$ in NYC (Li et al., 2006), the $\mathrm{HNO}_{3}$ produced via the heterogeneous reaction (R3) was quickly neutralized to ammonium nitrate. Submicron aerosol particles were indeed bulk neutralized throughout this study (Sun et al., 2011b). These formation processes together have led to a continuous increase of nitrate concentration. In addition, the high $\mathrm{RH}$ may also have facilitated the gas-to-particle partitioning of $\mathrm{HNO}_{3}$ and $\mathrm{NH}_{3}$. Our calculations using the Extended
AIM Aerosol Thermodynamics Model (E-AIM) (Clegg et al., 1998) (http://www.aim.env.uea.ac.uk/aim/aim.php) confirmed that the nitrate observed during this period existed completely in the aqueous-phase (Fig. 4). Overall, the concentration of nitrate increased from $0.4 \mu \mathrm{g} \mathrm{m}^{-3}$ to $\sim 4 \mu \mathrm{g} \mathrm{m}^{-3}$ in $\sim 8 \mathrm{~h}$, and its fractional contribution to total NR-PM 1 also elevated by 3 times from $\sim 15 \%$ to $50 \%$ (Fig. 1i). Note that much enhanced $\mathrm{NO}_{\mathrm{x}}, \mathrm{EC}, \mathrm{HOA}, \mathrm{CO}_{2}$, and toluene levels were observed at $\sim 23: 00,21$ July (Fig. 1), likely due to local traffic emissions. The apparent bimodal size distributions of organics during this time period (Fig. 2) further supported this conclusion. Due to elevated NO and VOCs (e.g. toluene) emissions, the $\mathrm{O}_{3}$ level was sharply reduced to a very low level (a few ppb), while $\mathrm{NO}_{2}$ increased to $\sim 20 \mathrm{ppb}$ (Fig. 1e). The increase of nitrate concentration lasted till $\sim 03: 00$ on 22 July, after which nitrate started to decrease. After sunrise at $\sim 04: 40$ (EST, Fig. 1), nitrate concentration continued to decrease until $\sim 09: 00$ (Fig. 4), consistent with the low equilibrium constant of $K_{\mathrm{p}}$ for the reaction (R7) (high $K_{\mathrm{p}}$ indicates more stable $\mathrm{NH}_{4} \mathrm{NO}_{3}$ ) (Seinfeld and Pandis, 2006) and the low photochemical production of $\mathrm{HNO}_{3}\left(\mathrm{NO}_{2} \times \mathrm{UV}\right.$ as a surrogate) via reaction (R6). Nitrate presented a second peak at noon on 22 July with the majority of it residing in the particle phase, mainly from gas-phase production via reactions of $\mathrm{NO}_{2}$ and $\mathrm{OH}$ at low $\mathrm{RH}(<60 \%)$. Nitrate finally decreased to a very low level after noon, associated with higher temperature $28^{\circ} \mathrm{C}$ and lower relative humidity $(60 \%)$, the decreasing photochemical production rate, and the rising boundary layer.

\subsection{Photochemical production of SOA}

Stage III represents the photochemical production of SOA(initially as SV-OOA) and sulfate from $\sim 06: 00$ to $\sim 18: 00$ on 22 July. This stage is characterized by relatively low RH $(\sim 60 \%)$, high temperature $\left(\sim 28^{\circ} \mathrm{C}\right)$, and light south 


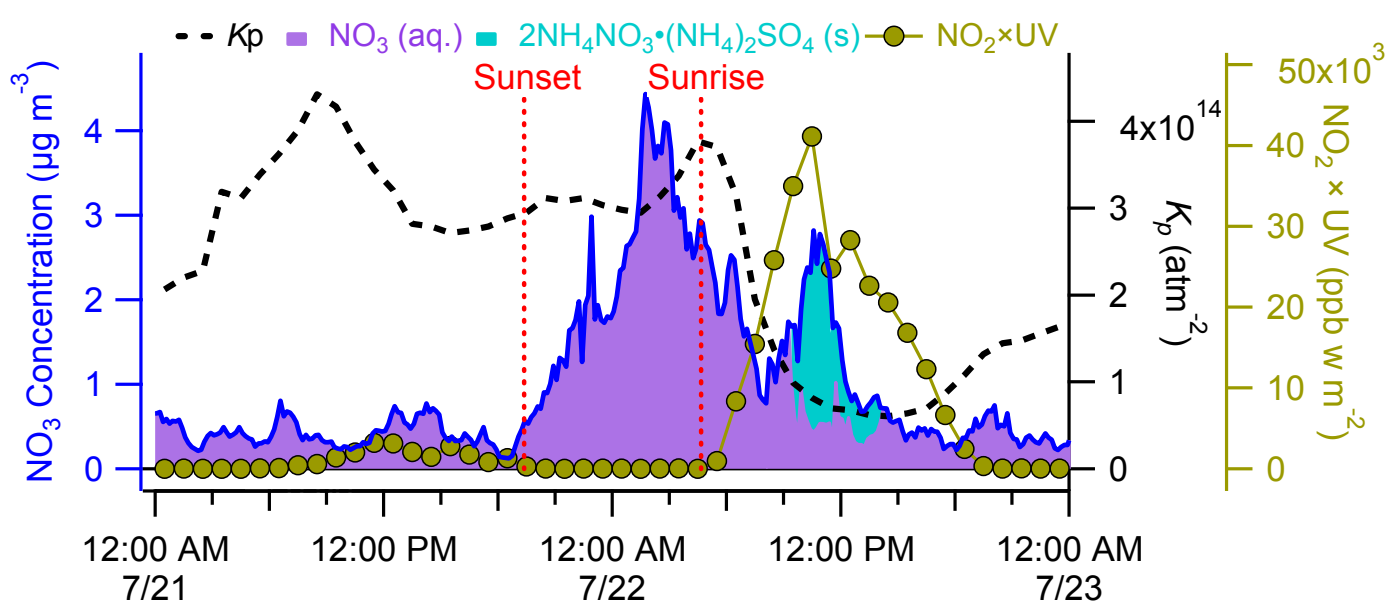

Fig. 4. Variations of nitrate in aqueous-phase and particle-phase from the Extended AIM Aerosol Thermodynamics Model (E-AIM) (Clegg et al., 1998) calculations, the equilibrium constant of $K_{\mathrm{p}}$ for $\mathrm{NH}_{4} \mathrm{NO}_{3}$ formation, $\mathrm{NO}_{2} \times \mathrm{UV}$, a surrogate of photochemical production rate of $\mathrm{HNO}_{3}$ at daytime.

wind $\left(0-3 \mathrm{~m} \mathrm{~s}^{-1}\right.$; Fig. 1b). The air was calm with wind speed close to zero from 06:00-11:00, during which SV-OOA gradually increased from 0.15 to $1.25 \mu \mathrm{g} \mathrm{m}^{-3}$ (Fig. 1f). Sulfate showed a simultaneous increase in concentration that continued till $\sim 18: 00$. The SV-OOA concentration peaked at $\sim 14: 00$. A rapid increase of LV-OOA began at $\sim 12: 00$ noon, at a nearly constant rate of $\sim 0.8 \mu \mathrm{g} \mathrm{m}^{-3} \mathrm{~h}^{-1}$ till 18:00 (Fig. 1f). It's interesting to note that the photo-oxidation processes during this period (06:00-18:00) appear to involve a continuum of evolution from the freshly oxidized and semivolatile species to highly oxidized and low volatility species, illustrated by the continuous increase of the $\mathrm{O} / \mathrm{C}$ ratio of OA from $\sim 0.1$, a value close to those of primary aerosols (e.g. diesel/gasoline and cooking) (Jimenez et al., 2009; Mohr et al., 2009; He et al., 2010) to above 0.5 (Fig. 1g). The evolution of $\mathrm{O} / \mathrm{C}$ was roughly linear with an increase rate of $\sim 0.035 \mathrm{~h}^{-1}$. The evolution of OA can be seen more clearly in Fig. 5a, in which the triangular region defined by two different slopes of $\mathrm{f} 44(\mathrm{~m} / \mathrm{z} 44 / \mathrm{OA})$ to $\mathrm{f} 43(\mathrm{~m} / \mathrm{z} 43 / \mathrm{OA})$ represents an integration of the relationship between $\mathrm{f} 44$ and f43 for the OOA components determined from PMF analysis of 43 AMS datasets at different sites ( $\mathrm{Ng}$ et al., 2010). As discussed in $\mathrm{Ng}$ et al. (2010), the less aged SV-OOA tends to occupy the broader base of the triangle while the more aged, regional LV-OOA tends to occupy the narrowing top region of the triangle with mass spectrum similar to those of fulvic acid and humic like substances (HULIS). Figure 5a shows that the OA particles bear close resemblance to HOA at the beginning of stage III, became more similar to SV-OOA within the first few hours of aging, and eventually became highly oxidized and close to LV-OOA. Note that the scavenging processes (Sect. 3.1) showed a reversed trend with a decrease of $\mathrm{f} 44$ and a simultaneous increase of $\mathrm{f} 43$. Similar evolution was also observed for OA across Europe as according to airborne studies of OA aging a function of distance from main emission sources (Morgan et al., 2010).

Formaldehyde (HCHO), an important intermediate product of photochemical oxidation, also showed a rapid increase from $\sim 1 \mathrm{ppb}$ to $5 \mathrm{ppb}$ in $\sim 8 \mathrm{~h}$ starting at $06: 00$ on 22 July (Fig. 1c). Detailed analysis of the sources of HCHO during this campaign showed that on average $\sim 60 \%$ of $\mathrm{HCHO}$ was produced from photochemical reactions, mainly oxidation of isoprene, methane, and propene (Lin et al., 2011). Given the short lifetime of $\mathrm{HCHO}$ (typically 3-4 h during the summertime conditions), the continuous increase of HCHO till 14:00 suggests that aerosol processing during the early stage III was most likely driven by local photochemical oxidation. The decrease of HCHO after 14:00 was likely due to photolysis and further oxidation by $\mathrm{OH}$ (Lin et al., 2011), consistent with the oxidation of SV-OOA to LV-OOA in the afternoon. $\mathrm{LV}-\mathrm{OOA}+\mathrm{SV}-\mathrm{OOA}$, a surrogate of SOA, shows tight correlation with $\mathrm{O}_{3}\left(r^{2}=0.84\right)$ but weaker correlation $\left(r^{2}=0.40\right)$ with $\mathrm{O}_{\mathrm{x}}\left(\mathrm{NO}_{2}+\mathrm{O}_{3}\right)$, likely due to an important contribution of $\mathrm{NO}_{2}$ from local emissions. Recent studies found that SOA and $\mathrm{O}_{\mathrm{x}}$ correlated well in air masses where they formed on similar timescales (less than $8 \mathrm{~h}$ ), but correlated poorly when their formation timescales or location differed greatly (Herndon et al., 2008; Wood et al., 2010). This is consistent with the tight correlations between $\mathrm{SOA}$ and $\mathrm{O}_{3}$ during this stage of photochemical production (06:00-18:00 on 22 July). The correlations between SOA and $\mathrm{O}_{3}$ or $\mathrm{O}_{\mathrm{x}}$ are overall weak for the entire study from 13 July to 3 August $\left(r^{2}=0.08\right.$ ) (Sun et al., 2011a).

In addition to local photochemical production, the atmospheric evolution of aerosol particles after 12:00 on 22 July was likely influenced by regional transport as well, given the increase of wind speed. Wind direction was consistently northerly during the whole stage. Back trajectory analysis 

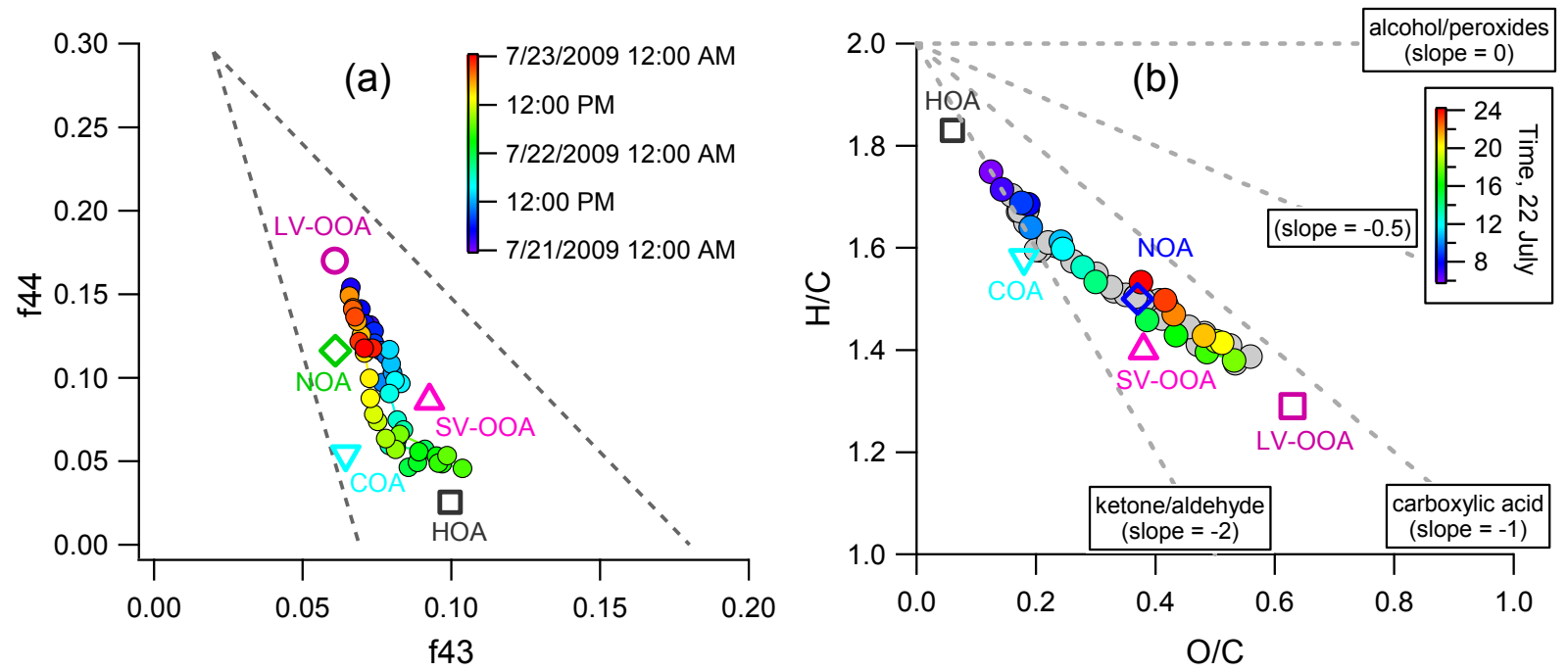

Fig. 5. (a) Relationship between $\mathrm{f} 44$ (fraction of $\mathrm{m} / \mathrm{z}, 44$ in the total organic signal) and $\mathrm{f} 43$ (fraction of $\mathrm{m} / \mathrm{z}, 43$ in the total organic signal) during 21-22 July. The f44 vs. 443 relationships for five OA factors identified during this study are also shown. The dash lines in (a) refer to a triangular region that encompasses ambient OOA factors determined from PMF analyses of 43 AMS datasets (Ng et al., 2010). More details are discussed in the main text. (b) Van Krevelen diagram for OA from 21-22 July and five OA components identified from PMF analyses. The dash lines in (b) indicate the changes of $\mathrm{H} / \mathrm{C}$ against $\mathrm{O} / \mathrm{C}$ due to adding specific functional groups to an aliphatic carbon (Heald et al., 2010).
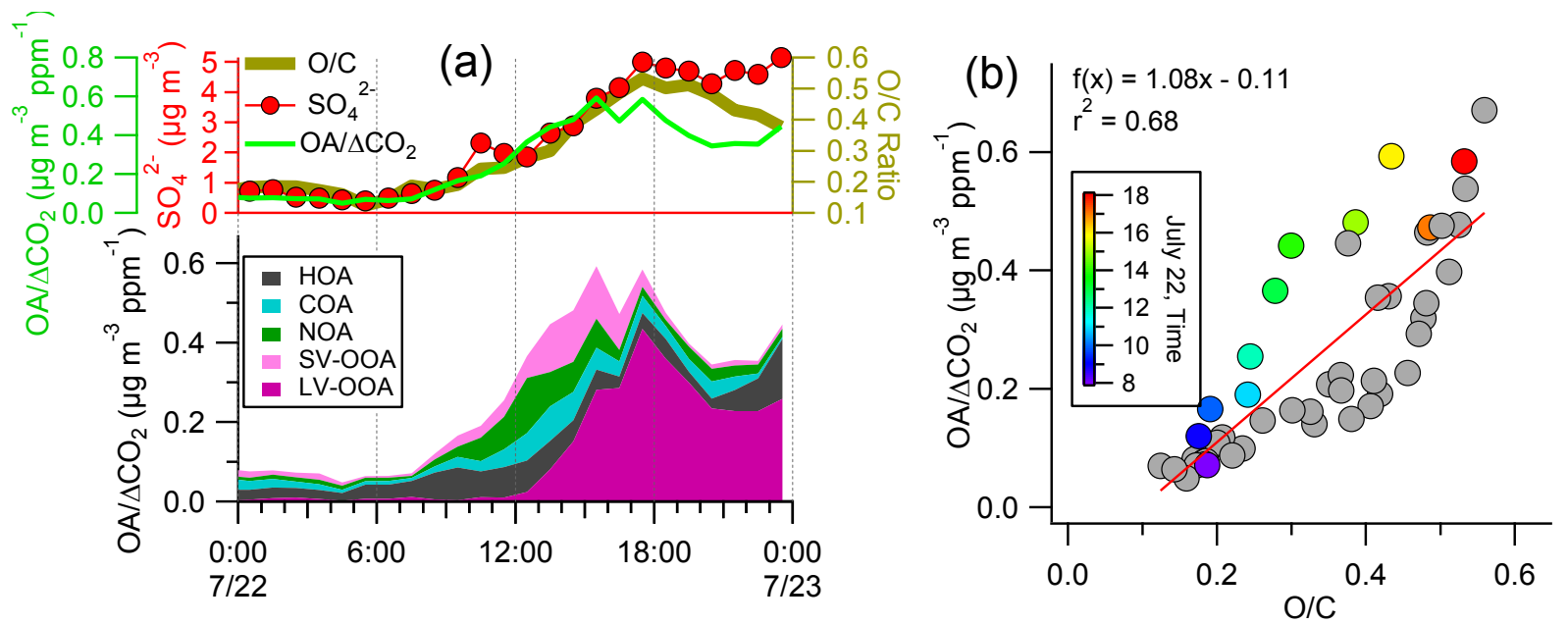

Fig. 6. Evolution of (a) $\mathrm{O} / \mathrm{C}$, sulfate, and $\mathrm{OA} / \Delta \mathrm{CO}_{2}$ on $22 \mathrm{July}$, (b) correlations between $\mathrm{OA} / \Delta \mathrm{CO}_{2}$ and $\mathrm{O} / \mathrm{C}$ ratio for the period of 21-22 July. The data points between 08:00-18:00 on 22 July are colored by the time.

in conjunction with the MODIS aerosol optical depth (AOD) observations showed that the air masses after 14:00 passed through the south of NYC where high AOD was observed (Fig. S3a). It should be noted that the retrieval of AOD on 22 July might be overestimated due to the extent of cloud cover over the south of NYC (Fig. S3b). In addition, Fig. S4 shows the variations of $\mathrm{PM}_{2.5}$ at different sites in NYC during 2122 July. Very similar temporal variation trends were observed at various downwind and upwind sites of QC during 21 July and 22 July. The increases on 22 July all started from very low ambient levels due to the heavy rainfall scavenging on 21 July, indicating a low regional background (at least in a radius of $\sim 40 \mathrm{~km}$ ) before stage III. Thus, we could argue that the aerosol evolution trend we observed during stage III may be representative of photochemical production over a relatively small regional scale.

The OA formation and evolution processes can be further investigated using the $\mathrm{OA} / \Delta \mathrm{CO}$ ratios $(\Delta \mathrm{CO}$ is the $\mathrm{CO}$ minus background $\mathrm{CO}$ ) to remove the atmospheric dilution effects (Dunlea et al., 2009; DeCarlo et al., 2010). Previous studies have shown that ambient OA can be rapidly oxidized in $\sim$ half day together with an increase of $\mathrm{OA}$ 


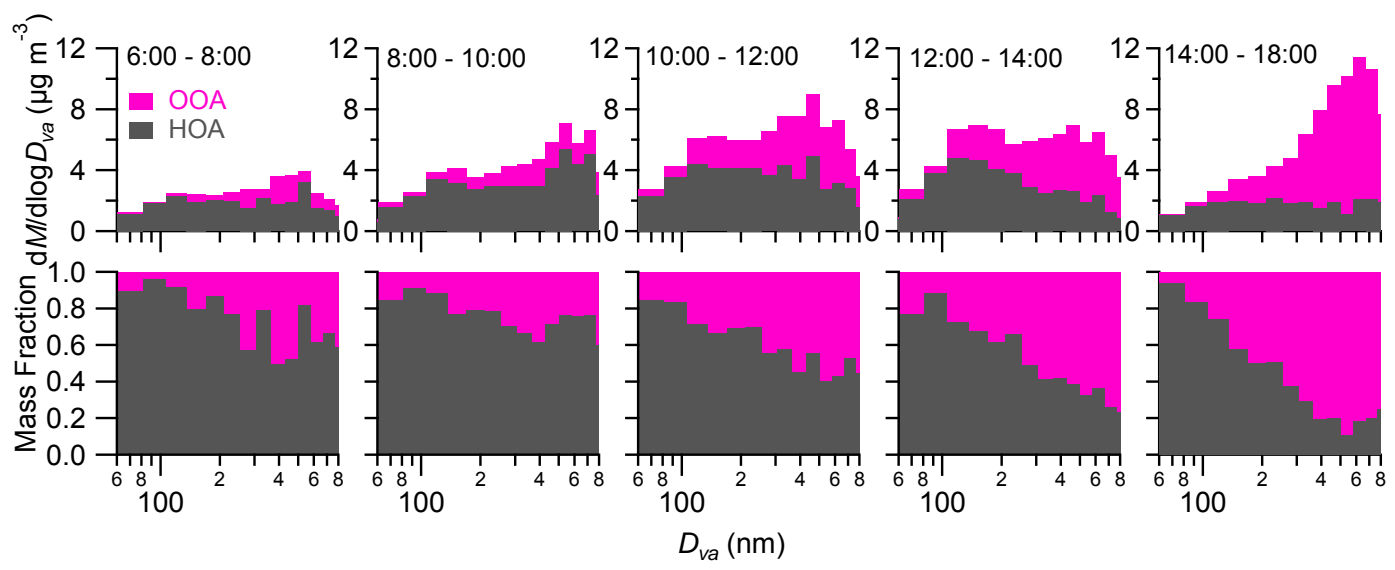

Fig. 7. Average size distributions of HOA and OOA for selected time ranges on 22 July. In each panel, the OOA size distribution is stacked on top of the HOA size distribution.

mass. Further oxidation of OA appears to affect OA mass to a lesser degree due to the counteractions of fragmentation of molecules and oxygen incorporation (Kroll et al., 2009). Given that we did not have CO measurements in this study, $\triangle \mathrm{CO}_{2}$ (mainly from combustion emissions) is used as a surrogate. A background $\mathrm{CO}_{2}$ of $340 \mathrm{ppm}$ was calculated as the lowest $5 \%$ of data during 21-22 July. The $\mathrm{OA} / \Delta \mathrm{CO}_{2}$ increased rapidly from $\sim 0.07 \mu \mathrm{g} \mathrm{m}^{-3} \mathrm{ppm}^{-1}$ to $\sim 0.6 \mathrm{\mu g} \mathrm{m}^{-3} \mathrm{ppm}^{-1}$ from 06:00 to 18:00 (Fig. 6a). The $\mathrm{HOA} / \Delta \mathrm{CO}_{2}$ and $\mathrm{COA} / \Delta \mathrm{CO}_{2}$ ratios were fairly constant throughout the entire period due to their primary sources from combustion emissions. The increases of $\mathrm{OA} / \Delta \mathrm{CO}_{2}$ were initially contributed by the semi-volatile species, and later dominated by LV-OOA. Also, the $\mathrm{O} / \mathrm{C}$ (a surrogate for photochemical age) shows tight correlations with $\mathrm{OA} / \Delta \mathrm{CO}_{2}$ (Fig. 6b) during the aging processes, consistent with previous results that the atmospheric aging of $\mathrm{OA}$ with $\mathrm{O} / \mathrm{C}$ $<0.5$ can lead to a quick formation of SOA mass (DeCarlo et al., 2010). It is also interesting to note that the $C$ and $\mathrm{O}$ contents in OA showed simultaneous increases but faster for O (Fig. S5), indicating that oxygen incorporation might have played a major role in the aging of SV-OOA, in agreement with the results from chamber experiments (Kroll et al., 2009). Figure $5 \mathrm{~b}$ shows the Van Krevelen diagram (H/C vs. O/C) for OA during 21-22 July. During the early stage of oxidation $(\mathrm{O} / \mathrm{C}<0.2)$, the evolution of $\mathrm{H} / \mathrm{C}$ versus $\mathrm{O} / \mathrm{C}$ presents a steeper slope than -1 reported by Heald et al. (2010), likely due to the addition of carbonyl group and possibly the initial heterogeneous oxidation of POA species (Ng et al., 2011). A further oxidation of OA after 12:00 appears to show a shallower slope $(-0.7)$, suggesting a different evolution process. An investigation of such evolution for OOA components observed at various sites shows similar shallower slope $(-0.5)$, probably due to the additions of both acid and alcohol functional groups with less fragmentation (Ng et al., 2011). This is in agreement with simulta- neous increases of both $\mathrm{fCO}_{2}^{+}$(fraction of $\mathrm{CO}_{2}^{+}$in $\mathrm{OA}$ ) and $\mathrm{fC}_{2} \mathrm{H}_{3} \mathrm{O}^{+}$(fraction of $\mathrm{C}_{2} \mathrm{H}_{3} \mathrm{O}^{+}$in $\mathrm{OA}$ ) in the triangle plot of $\mathrm{fCO}_{2}^{+}$vs. $\mathrm{fC}_{2} \mathrm{H}_{3} \mathrm{O}^{+}$(Fig. S6). The OA/ $\Delta \mathrm{CO}_{2}$ started to decrease after $\sim 18: 00$, and the $\mathrm{C}$ and $\mathrm{O}$ contents followed the same trend. In addition, we didn't observe further oxidation of $\mathrm{OA}$ to higher $\mathrm{O} / \mathrm{C}$, but a gradual decrease of $\mathrm{O} / \mathrm{C}$ from $\sim 0.5$ to $\sim 0.4$ after 18:00 due to increased contributions from local emissions during this study. However, oxidation of OA up to O/C of $\sim 0.9-1$ was observed from the aircraft measurements during MILAGRO (DeCarlo et al., 2010).

Interestingly, the increase of LV-OOA was $\sim 5 \mathrm{~h}$ behind the photochemical production of sulfate and SV-OOA (Fig. 1), both of which started at $\sim 06: 00$, demonstrating differences in the formation mechanisms of sulfate and LV-OOA. E-AIM model calculations show that sulfate mainly existed in particle phase as $\left(\mathrm{NH}_{4}\right)_{2} \mathrm{SO}_{4}$ and $2 \mathrm{NH}_{4} \mathrm{NO}_{3}\left(\mathrm{NH}_{4}\right)_{2} \mathrm{SO}_{4}$, and a very minor fraction in aqueous-phase. This suggests that the local gas-phase bi-molecular reaction of $\mathrm{SO}_{2}$ and $\mathrm{OH}$ was likely the dominant formation process of sulfate during this stage. Comparatively, the formation of LV-OOA involves a longer but continuous oxidation from volatile and semi-volatile species accompanied by evolutions of volatilities and functionalities. Results here indicate that secondary formation of sulfate occurred earlier than LV-OOA. The ratio of LV-OOA/SO $\mathrm{SO}_{4}^{2-}$ was $\sim 0.1$ at the beginning, gradually increased to $\sim 1$ as a function of photochemical age, and became stable during the highly aged period (Fig. S7c). Zhang et al. (2007b) also found an average lower OOA/ $\mathrm{SO}_{4}^{2-}$ ratio in acidic particles than in neutralized particles in Pittsburgh. However, over longer time scales, LV-OOA and sulfate would become more internally mixed and show better correlations since both are secondary species formed on regional scales (Zhang et al., 2005a, c; Ulbrich et al., 2009; DeCarlo et al., 2010; Sun et al., 2011a). Overall, our results suggest that the temporal correlation of LV-OOA and sulfate concentrations is likely dependent on the oxidation degree of 
aerosols. The correlation could be poor in the early stage of photochemical process due to differences in oxidation rates and reaction pathways.

The detailed size evolution of organics, sulfate, and nitrate during stage III is shown in Fig. 2. Organics showed a significant ultrafine mode between $\sim 09: 00-14: 00$, and the average size distributions presented distinct bimodal distributions, peaking at $\sim 150 \mathrm{~nm}$ and $\sim 500 \mathrm{~nm}$ respectively. The persistent ultrafine mode of organics together with the synchronous increases of $\mathrm{NO}_{\mathrm{x}}, \mathrm{EC}$, and HOA (Fig. 1) suggests the dominant contribution from local emissions rather than regional transport. After a few hours of aging, the ultrafine mode OA concentration significantly reduced, accompanied by a large enhancement of the accumulation mode. In addition, the size distribution of organics after $\sim$ half day of aging resembled more to that of sulfate, indicating that atmospheric aging would lead to a change in aerosol mixing state, e.g. from external mixture to more internally mixed, possibly due to aqueous phase processing. Figure 7 shows the average size distributions of HOA and OOA for selected time intervals during stage III. HOA dominated the OA composition across the whole size range with an average contribution close to $60 \%$ before 10:00. After 10:00, we observed a decrease in HOA in the accumulation mode and an increase of OOA due to atmospheric dilution associated with increase of PBL depth and production of SOA. During 14:00-18:00, OOA comprised up to $\sim 80 \%$ of the bulk total OA mass, though HOA was still the major component of the ultrafine mode. The size distributions of sulfate appear to change from a broader to a narrower accumulation mode with the peak values shifting to larger sizes as well during the photochemical evolution processes.

\section{Conclusions}

A case study from 21-22 July during the summer 2009 Field Intensive Study at QC in NYC was investigated in detail to characterize three typical aerosol processes including wet scavenging, nighttime nitrate formation, and photochemical production and processing of secondary aerosol species. The wet scavenging efficiencies of aerosol species appear to be strongly related to their hygroscopicities and mixing states. The apparent scavenging ratios follow the order of sulfate $>$ LV-OOA $>$ SV-OOA $>$ HOA, leading to a significant change in aerosol composition with reduced contribution of SOA and inorganic species during rainfall scavenging events. The wet scavenging also leads to a rapid decrease of the average oxidation state of OA. The second stage is characterized by a quick nighttime formation of nitrate, presumably from heterogeneous reaction of $\mathrm{N}_{2} \mathrm{O}_{5}$. A second peak in nitrate time series was observed due to daytime photochemical reactions of $\mathrm{NO}_{2}$ and $\mathrm{OH}$. In the third stage, a local photochemical process that started at $\sim 06: 00$ of the second day and persisted for $\sim$ half day was observed. Results show that aerosol particles can be oxidized to a high degree in $\sim$ half day, consistent with previously reported results from CO-tracer method $(\mathrm{OA} / \Delta \mathrm{CO})$. Detailed analysis of the oxidation processes suggests that OA evolution appears to involve a continuum of oxidation processes from semi-volatile to low-volatility species, and external to internal mixtures. The size distributions of OA evolved from bimodal (peaking at $\sim 150 \mathrm{~nm}$ and $500 \mathrm{~nm}$ ) to a single large accumulation mode. This evolutionary process is characterized by a delay of a few hours in the increase of LV-OOA concentration compared to that of sulfate. In addition, functionalization by incorporation of both $\mathrm{C}$ and $\mathrm{O}$ atoms in $\mathrm{OA}$ molecules seems to have played a major role in the early period of evolution of $\mathrm{OA}(\mathrm{O} / \mathrm{C}<0.5)$.

\section{Supplementary material related to this article is available online at: http://www.atmos-chem-phys.net/11/12737/2011/ acp-11-12737-2011-supplement.pdf.}

Acknowledgements. This research was supported by the One Hundred Person Project of the Chinese Academy of Sciences, the Office of Science (BER), US Department of Energy, Atmospheric Systems Research (ASR) Program (Grants No. DE-FG02-08ER64627, DESC0002191), New York State Energy Research and Development Authority, New York State Department of Environmental Conservation, and New York State Office of Science, Technology and Academic Research. We acknowledge our Aerodyne colleagues for sharing equipment and useful discussions during the campaign. We thank the New York State Department of Environmental Conservation for use of their facility, and particularly Mike Christopherson, Ed Marion, and Dirk Felton. We thank the Queens College administration and staff, especially Wing Chan, for hosting this study.

Edited by: A. Kiendler-Scharr

\section{References}

Andronache, C.: Estimated variability of below-cloud aerosol removal by rainfall for observed aerosol size distributions, Atmos. Chem. Phys., 3, 131-143, doi:10.5194/acp-3-131-2003, 2003.

Brown, S. S., Ryerson, T. B., Wollny, A. G., Brock, C. A., Peltier, R., Sullivan, A. P., Weber, R. J., Dube, W. P., Trainer, M., Meagher, J. F., Fehsenfeld, F. C., and Ravishankara, A. R.: Variability in Nocturnal Nitrogen Oxide Processing and Its Role in Regional Air Quality, Science, 311, 67-70, doi:10.1126/science.1120120, 2006.

Chang, R. Y.-W., Slowik, J. G., Shantz, N. C., Vlasenko, A., Liggio, J., Sjostedt, S. J., Leaitch, W. R., and Abbatt, J. P. D.: The hygroscopicity parameter $(\kappa)$ of ambient organic aerosol at a field site subject to biogenic and anthropogenic influences: relationship to degree of aerosol oxidation, Atmos. Chem. Phys., 10, 50475064, doi:10.5194/acp-10-5047-2010, 2010.

Clegg, S. L., Brimblecombe, P., and Wexler, A. S.: A thermodynamic model of the system $\mathrm{H}^{+}-\mathrm{NH}_{4}^{+}-\mathrm{SO}_{2}^{-}-\mathrm{NO}_{3}^{-}-\mathrm{H}_{2} \mathrm{O}$ at 
tropospheric temperatures, J. Phys. Chem. A, 102, 2137-2154, 1998.

DeCarlo, P. F., Kimmel, J. R., Trimborn, A., Northway, M. J., Jayne, J. T., Aiken, A. C., Gonin, M., Fuhrer, K., Horvath, T., Docherty, K. S., Worsnop, D. R., and Jimenez, J. L.: Field-Deployable, High-Resolution, Time-of-Flight Aerosol Mass Spectrometer, Anal. Chem., 78, 8281-8289, 2006.

DeCarlo, P. F., Ulbrich, I. M., Crounse, J., de Foy, B., Dunlea, E. J., Aiken, A. C., Knapp, D., Weinheimer, A. J., Campos, T., Wennberg, P. O., and Jimenez, J. L.: Investigation of the sources and processing of organic aerosol over the Central Mexican Plateau from aircraft measurements during MILAGRO, Atmos. Chem. Phys., 10, 5257-5280, doi:10.5194/acp-10-52572010, 2010.

Drewnick, F., Schwab, J. J., Jayne, J. T., Canagaratna, M., Worsnop, D. R., and Demerjian, K. L.: Measurement of ambient aerosol composition during the PMTACS-NY 2001 using an Aerosol Mass Spectrometer. Part I: Mass concentrations, Aerosol Sci. Tech., 38, 92-103, 2004a.

Drewnick, F., Schwab, J. J., Jayne, J. T., Canagaratna, M., Worsnop, D. R., and Demerjian, K. L.: Measurement of ambient aerosol composition during the PMTACS-NY 2001 using an Aerosol Mass Spectrometer. Part II: Chemically speciated mass distributions, Aerosol Sci. Tech., 38, 104-117, 2004b.

Drewnick, F., Hings, S. S., DeCarlo, P. F., Jayne, J. T., Gonin, M., Fuhrer, K., Weimer, S., Jimenez, J. L., Demerjian, K. L., Borrmann, S., and Worsnop, D. R.: A new Time-of-Flight Aerosol Mass Spectrometer (ToF-AMS) - Instrument description and first field deployment., Aerosol Sci. Tech., 39, 637-658, 2005.

Dunlea, E. J., DeCarlo, P. F., Aiken, A. C., Kimmel, J. R., Peltier, R. E., Weber, R. J., Tomlinson, J., Collins, D. R., Shinozuka, Y., McNaughton, C. S., Howell, S. G., Clarke, A. D., Emmons, L. K., Apel, E. C., Pfister, G. G., van Donkelaar, A., Martin, R. V., Millet, D. B., Heald, C. L., and Jimenez, J. L.: Evolution of Asian aerosols during transpacific transport in INTEX-B, Atmos. Chem. Phys., 9, 7257-7287, doi:10.5194/acp-9-7257-2009, 2009.

Dzepina, K., Volkamer, R. M., Madronich, S., Tulet, P., Ulbrich, I. M., Zhang, Q., Cappa, C. D., Ziemann, P. J., and Jimenez, J. L.: Evaluation of recently-proposed secondary organic aerosol models for a case study in Mexico City, Atmos. Chem. Phys., 9, 5681-5709, doi:10.5194/acp-9-5681-2009, 2009.

Forster, P., Ramaswamy, V., Artaxo, P., Berntsen, T., Betts, R., Fahey, D. W., Haywood, J., Lean, J., Lowe, D. C., Myhre, G., Nganga, J., Prinn, R., Raga, G., Schulz, M., and Dorland, R. V.: Changes in Atmospheric Constituents and in Radiative Forcing., in: Climate Change 2007: The Physical Science Basis. Contribution of Working Group I to the Fourth Assessment Report of the Intergovernmental Panel on Climate Change, edited by: Solomon, S., Qin, D., Manning, M., Chen, Z., Marquis, M., Averyt, K. B., Tignor, M., and Miller, H. L., Cambridge University Press, Cambridge, United Kingdom and New York, NY, USA., 2007.

Hallquist, M., Wenger, J. C., Baltensperger, U., Rudich, Y., Simpson, D., Claeys, M., Dommen, J., Donahue, N. M., George, C., Goldstein, A. H., Hamilton, J. F., Herrmann, H., Hoffmann, T., Iinuma, Y., Jang, M., Jenkin, M. E., Jimenez, J. L., Kiendler-Scharr, A., Maenhaut, W., McFiggans, G., Mentel, Th. F., Monod, A., Prévôt, A. S. H., Seinfeld, J. H., Surratt, J. D.,
Szmigielski, R., and Wildt, J.: The formation, properties and impact of secondary organic aerosol: current and emerging issues, Atmos. Chem. Phys., 9, 5155-5236, doi:10.5194/acp-95155-2009, 2009.

He, L. Y., Lin, Y., Huang, X. F., Guo, S., Xue, L., Su, Q., Hu, M., Luan, S. J., and Zhang, Y. H.: Characterization of high-resolution aerosol mass spectra of primary organic aerosol emissions from Chinese cooking and biomass burning, Atmos. Chem. Phys., 10, 11535-11543, doi:10.5194/acp-10-11535-2010, 2010.

Heald, C. L., Jacob, D. J., Park, R. J., Russell, L. M., Huebert, B. J., Seinfeld, J. H., Liao, H., and Weber, R. J.: A large organic aerosol source in the free troposphere missing from current models, Geophys. Res. Lett., 32, L18809, doi:10.1029/2005GL023831, 2005.

Heald, C. L., Kroll, J. H., Jimenez, J. L., Docherty, K. S., DeCarlo, P. F., Aiken, A. C., Chen, Q., Martin, S. T., Farmer, D. K., and Artaxo, P.: A simplified description of the evolution of organic aerosol composition in the atmosphere, Geophys. Res. Lett., 37, L08803, doi:10.1029/2010g1042737, 2010.

Herndon, S. C., Onasch, T. B., Wood, E. C., Kroll, J. H., Canagaratna, M. R., Jayne, J. T., Zavala, M. A., Knighton, W. B., Mazzoleni, C., Dubey, M. K., Ulbrich, I. M., Jimenez, J. L., Seila, R., de Gouw, J. A., de Foy, B., Fast, J., Molina, L. T., Kolb, C. E., and Worsnop, D. R.: Correlation of secondary organic aerosol with odd oxygen in Mexico City, Geophys. Res. Lett., 35, L15804, doi:10.1029/2008g1034058, 2008.

Huang, X. F., He, L. Y., Hu, M., Canagaratna, M. R., Sun, Y., Zhang, Q., Zhu, T., Xue, L., Zeng, L. W., Liu, X. G., Zhang, Y. H., Jayne, J. T., Ng, N. L., and Worsnop, D. R.: Highly time-resolved chemical characterization of atmospheric submicron particles during 2008 Beijing Olympic Games using an Aerodyne High-Resolution Aerosol Mass Spectrometer, Atmos. Chem. Phys., 10, 8933-8945, doi:10.5194/acp-10-8933-2010, 2010.

IPCC: Summary for Policymakers., In: Climate Change 2007: The Physical Science Basis. Contribution of Working Group I to the Fourth Assessment Report of the Intergovernmental Panel on Climate Change, edited by: Solomon, S., Qin, D., Manning, M., Chen, Z., Marquis, M., Averyt, K. B., Tignor, M., and Miller, H. L., Cambridge University Press, Cambridge, United Kingdom and New York, NY, USA., 2007.

Jayne, J. T., Leard, D. C., Zhang, X., Davidovits, P., Smith, K. A., Kolb, C. E., and Worsnop, D. R.: Development of an aerosol mass spectrometer for size and composition analysis of submicron particles, Aerosol Sci. Tech., 33, 49-70, 2000.

Jimenez, J. L., Jayne, J. T., Shi, Q., Kolb, C. E., Worsnop, D. R., Yourshaw, I., Seinfeld, J. H., Flagan, R. C., Zhang, X., Smith, K. A., Morris, J. W., and Davidovits, P.: Ambient aerosol sampling with an Aerosol Mass Spectrometer, J. Geophys. Res.-Atmos., 108, 8425, doi:10:1029/2001JD001213, 2003.

Jimenez, J. L., Canagaratna, M. R., Donahue, N. M., Prevot, A. S. H., Zhang, Q., Kroll, J. H., DeCarlo, P. F., Allan, J. D., Coe, H., Ng, N. L., Aiken, A. C., Docherty, K. S., Ulbrich, I. M., Grieshop, A. P., Robinson, A. L., Duplissy, J., Smith, J. D., Wilson, K. R., Lanz, V. A., Hueglin, C., Sun, Y. L., Tian, J., Laaksonen, A., Raatikainen, T., Rautiainen, J., Vaattovaara, P., Ehn, M., Kulmala, M., Tomlinson, J. M., Collins, D. R., Cubison, M. J., E, Dunlea, J., Huffman, J. A., Onasch, T. B., Alfarra, M. R., Williams, P. I., Bower, K., Kondo, Y., Schneider, J., Drewnick, 
F., Borrmann, S., Weimer, S., Demerjian, K., Salcedo, D., Cottrell, L., Griffin, R., Takami, A., Miyoshi, T., Hatakeyama, S., Shimono, A., Sun, J. Y., Zhang, Y. M., Dzepina, K., Kimmel, J. R., Sueper, D., Jayne, J. T., Herndon, S. C., Trimborn, A. M., Williams, L. R., Wood, E. C., Middlebrook, A. M., Kolb, C. E., Baltensperger, U., and Worsnop, D. R.: Evolution of organic aerosols in the atmosphere, Science, 326, 1525-1529, doi:10.1126/science.1180353, 2009.

Kanakidou, M., Seinfeld, J. H., Pandis, S. N., Barnes, I., Dentener, F. J., Facchini, M. C., Van Dingenen, R., Ervens, B., Nenes, A., Nielsen, C. J., Swietlicki, E., Putaud, J. P., Balkanski, Y., Fuzzi, S., Horth, J., Moortgat, G. K., Winterhalter, R., Myhre, C. E. L., Tsigaridis, K., Vignati, E., Stephanou, E. G., and Wilson, J.: Organic aerosol and global climate modelling: a review, Atmos. Chem. Phys., 5, 1053-1123, doi:10.5194/acp-5-1053-2005, 2005.

Kroll, J. H., Smith, J. D., Che, D. L., Kessler, S. H., Worsnop, D. R., and Wilson, K. R.: Measurement of fragmentation and functionalization pathways in the heterogeneous oxidation of oxidized organic aerosol, Phys. Chem. Chem. Phys., 11, 8005-8014, 2009.

Li, Y., Schwab, J. J., and Demerjian, K. L.: Measurements of ambient ammonia using a tunable diode laser absorption spectrometer: Characteristics of ambient ammonia emissions in an urban area of New York City, J. Geophys. Res., 111, D10S02, doi:10.1029/2005jd006275, 2006.

Limbeck, A. and Puxbaum, H.: Dependence of in-cloud scavenging of polar organic aerosol compounds on the water solubility, J. Geophys. Res., 105, 19857-19867, doi:10.1029/2000JD900123, 2000.

Lin, Y. C., Schwab, J. J., Demerjian, K. L., Bae, M.-S., Chen, W.N., Sun, Y., Zhang, Q., Hung, H.-M., and Perry, J.: Summertime Formaldehyde Observations in New York City: Ambient levels, Sources and Its Contribution to HOx Radicals, J. Geophys. Res., submitted, 2011.

Liu, P. S. K., Deng, R., Smith, K. A., Williams, L. R., Jayne, J. T., Canagaratna, M. R., Moore, K., Onasch, T. B., Worsnop, D. R., and Deshler, T.: Transmission efficiency of an aerodynamic focusing lens system: Comparison of model calculations and laboratory measurements for the Aerodyne Aerosol Mass Spectrometer, Aerosol Sci. Tech., 41, 721-733, 2007.

Massoli, P., Lambe, A. T., Ahern, A. T., Williams, L. R., Ehn, M., Mikkilä, J., Canagaratna, M. R., Brune, W. H., Onasch, T. B., Jayne, J. T., Petäjä, T., Kulmala, M., Laaksonen, A., Kolb, C. E., Davidovits, P., and Worsnop, D. R.: Relationship between aerosol oxidation level and hygroscopic properties of laboratory generated secondary organic aerosol (SOA) particles, Geophys. Res. Lett., 37, L24801, doi:10.1029/2010g1045258, 2010.

Mohr, C., Huffman, J. A., Cubison, M. J., Aiken, A. C., Docherty, K. S., Kimmel, J. R., Ulbrich, I. M., Hannigan, M., and Jimenez, J. L.: Characterization of primary organic aerosol emissions from meat cooking, trash burning, and motor vehicles with HighResolution Aerosol Mass Spectrometry and comparison with ambient and chamber observations, Environ. Sci. Technol., 43, 2443-2449, doi:10.1021/es8011518, 2009.

Molina, M. J. and Molina, L. T.: Megacities and atmospheric pollution, J. Air Waste Manage. Assoc., 54, 644-680, 2004.

Morgan, W. T., Allan, J. D., Bower, K. N., Highwood, E. J., Liu, D., McMeeking, G. R., Northway, M. J., Williams, P. I., Krejci, R., and Coe, H.: Airborne measurements of the spatial distribu- tion of aerosol chemical composition across Europe and evolution of the organic fraction, Atmos. Chem. Phys., 10, 4065-4083, doi:10.5194/acp-10-4065-2010, 2010.

Ng, N. L., Canagaratna, M. R., Zhang, Q., Jimenez, J. L., Tian, J., Ulbrich, I. M., Kroll, J. H., Docherty, K. S., Chhabra, P. S., Bahreini, R., Murphy, S. M., Seinfeld, J. H., Hildebrandt, L., Donahue, N. M., DeCarlo, P. F., Lanz, V. A., Prévôt, A. S. H., Dinar, E., Rudich, Y., and Worsnop, D. R.: Organic aerosol components observed in Northern Hemispheric datasets from Aerosol Mass Spectrometry, Atmos. Chem. Phys., 10, 46254641, doi:10.5194/acp-10-4625-2010, 2010.

Ng, N. L., Canagaratna, M. R., Jimenez, J. L., Chhabra, P. S., Seinfeld, J. H., and Worsnop, D. R.: Changes in organic aerosol composition with aging inferred from aerosol mass spectra, Atmos. Chem. Phys., 11, 6465-6474, doi:10.5194/acp-11-64652011, 2011.

Paatero, P. and Tapper, U.: Positive matrix factorization: A nonnegative factor model with optimal utilization of error estimates of data values, Environmetrics, 5, 111-126, 1994.

Petters, M. D., Carrico, C. M., Kreidenweis, S. M., Prenni, A. J., DeMott, P. J., Collett, J. L., Jr., and Moosmuller, H.: Cloud condensation nucleation activity of biomass burning aerosol, J. Geophys. Res., 114, D22205, doi:10.1029/2009jd012353, 2009.

Pope, C. A. III, Burnett, R. T., Thun, M. J., Calle, E. E., Krewski, D., Ito, K., and Thurston, G. D.: Lung cancer, cardiopulmonary mortality, and long-term exposure to fine particulate air pollution, JAMA-J. Am. Med. Assoc., 287, 1132-1141, 2002.

Pope, C. A. III, Ezzati, M., and Dockery, D. W.: Fine-particulate air pollution and life expectancy in the United States, N. Engl. J. Med., 360, 376-386, doi:10.1056/NEJMsa0805646, 2009.

Pöschl, U.: Atmospheric aerosols: Composition, transformation, climate and health effects, Angewandte Chemie-International Edition, 44, 7520-7540, 2005.

Seinfeld, J. H. and Pandis, S. N.: Atmospheric chemistry and physics: from air pollution to climate change, Wiley, John \& Sons, Incorporated, New York, 1203 pp., 2006.

Sellegri, K., Laj, P., Dupuy, R., Legrand, M., Preunkert, S., and Putaud, J. P.: Size-dependent scavenging efficiencies of multicomponent atmospheric aerosols in clouds, J. Geophys. Res., 108, 4334, doi:4310.1029/2002JD002749, 2003.

Sueper, D.: ToF-AMS Analysis Software, available at: http://cires.colorado.edu/jimenez-group/ToFAMSResources/ ToFSoftware/index.html, last access: 2 June 2011, 2011.

Sun, J., Zhang, Q., Canagaratna, M. R., Zhang, Y., Ng, N. L., Sun, Y., Jayne, J. T., Zhang, X., Zhang, X., and Worsnop, D. R.: Highly time- and size-resolved characterization of submicron aerosol particles in Beijing using an Aerodyne Aerosol Mass Spectrometer, Atmos. Environ., 44, 131-140, doi:10.1016/j.atmosenv.2009.03.020, 2010.

Sun, Y. L., Zhang, Q., Schwab, J. J., Demerjian, K. L., Chen, W. N., Bae, M. S., Hung, H. M., Hogrefe, O., Frank, B., Rattigan, O. V., and Lin, Y. C.: Characterization of the sources and processes of organic and inorganic aerosols in New York city with a high-resolution time-of-flight aerosol mass apectrometer, Atmos. Chem. Phys., 11, 1581-1602, doi:10.5194/acp-11-15812011, 2011a.

Sun, Y. L., Zhang, Q., Zheng, M., Ding, X., Edgerton, E. S., and Wang, X.: Characterization and source apportionment of watersoluble organic matter in atmospheric fine particles $\left(\mathrm{PM}_{2.5}\right)$ with 
High-Resolution Aerosol Mass Spectrometry and GC-MS, Environ. Sci. Technol., 45, 4854-4861, doi:10.1021/es200162h, $2011 b$

Ulbrich, I. M., Canagaratna, M. R., Zhang, Q., Worsnop, D. R., and Jimenez, J. L.: Interpretation of organic components from Positive Matrix Factorization of aerosol mass spectrometric data, Atmos. Chem. Phys., 9, 2891-2918, doi:10.5194/acp-9-2891-2009, 2009.

Volkamer, R., Jimenez, J. L., Martini, F. S., Dzepina, K., Zhang, Q., Salcedo, D., Molina, L. T., Molina, M. J., and Worsnop, D. R.: Secondary organic aerosol formation from anthropogenic VOCs: Rapid and higher than expected, Geophys. Res. Lett., 33, L17811, doi:10.1029/2006GL026899, 2006.

Watson, J. G.: Visibility: Science and regulation, J. Air Waste Manage. Assoc., 52, 628-713, 2002.

Weimer, S., Drewnick, F., Hogrefe, O., Schwab, J. J., Rhoads, K., Orsini, D., Canagaratna, M., Worsnop, D. R., and Demerjian, K. L.: Size-selective nonrefractory ambient aerosol measurements during the Particulate Matter Technology Assessment and Characterization Study - New York 2004 Winter Intensive in New York City, J. Geophys. Res., 111, D18305, doi:10.1029/2006JD007215, 2006.

Wood, E. C., Canagaratna, M. R., Herndon, S. C., Onasch, T. B., Kolb, C. E., Worsnop, D. R., Kroll, J. H., Knighton, W. B., Seila, R., Zavala, M., Molina, L. T., DeCarlo, P. F., Jimenez, J. L., Weinheimer, A. J., Knapp, D. J., Jobson, B. T., Stutz, J., Kuster, W. C., and Williams, E. J.: Investigation of the correlation between odd oxygen and secondary organic aerosol in Mexico City and Houston, Atmos. Chem. Phys., 10, 8947-8968, doi:10.5194/acp-10-8947-2010, 2010.

Zhang, Q., Alfarra, M. R., Worsnop, D. R., Allan, J. D., Coe, H., Canagaratna, M. R., and Jimenez, J. L.: Deconvolution and quantification of hydrocarbon-like and oxygenated organic aerosols based on aerosol mass spectrometry, Environ. Sci. Technol., 39, 4938-4952, doi:10.1021/es0485681, 2005a.
Zhang, Q., Canagaratna, M. C., Jayne, J. T., Worsnop, D. R., and Jimenez, J. L.: Time and size-resolved chemical composition of submicron particles in Pittsburgh - Implications for aerosol sources and processes, J. Geophys. Res., 110, D07S09, doi:10.1029/2004JD004649, 2005b.

Zhang, Q., Worsnop, D. R., Canagaratna, M. R., and Jimenez, J. L.: Hydrocarbon-like and oxygenated organic aerosols in Pittsburgh: insights into sources and processes of organic aerosols, Atmos. Chem. Phys., 5, 3289-3311, doi:10.5194/acp-5-32892005, 2005c.

Zhang, Q., Jimenez, J. L., Canagaratna, M. R., Allan, J. D., Coe, H., Ulbrich, I., Alfarra, M. R., Takami, A., Middlebrook, A. M., Sun, Y. L., Dzepina, K., Dunlea, E., Docherty, K., DeCarlo, P. F., Salcedo, D., Onasch, T., Jayne, J. T., Miyoshi, T., Shimono, A., Hatakeyama, S., Takegawa, N., Kondo, Y., Schneider, J., Drewnick, F., Weimer, S., Demerjian, K., Williams, P., Bower, K., Bahreini, R., Cottrell, L., R.J.Griffin, Rautiainen, J., Sun, J. Y., Zhang, Y. M., and Worsnop, D. R.: Ubiquity and dominance of oxygenated species in organic aerosols in anthropogenicallyinfluenced northern hemisphere mid-latitudes, Geophys. Res. Lett., 34, L13801, doi:10.1029/2007GL029979, 2007a.

Zhang, Q., Jimenez, J. L., Worsnop, D. R., and Canagaratna, M.: A case study of urban particle acidity and its effect on secondary organic aerosol, Environ. Sci. Technol., 41, 3213-3219, doi:10.1021/es061812j, 2007b.

Zhang, Q., Jimenez, J., Canagaratna, M., Ulbrich, I., Ng, N., Worsnop, D., and Sun, Y.: Understanding atmospheric organic aerosols via factor analysis of aerosol mass spectrometry: a review, Anal. Bioanal. Chem., 401, 3045-3067, doi:10.1007/s00216-011-5355-y, 2011. 